\title{
DISQUIETING DEGENERACY: \\ POLICING MALAYSIAN AND SINGAPOREAN POPULAR MUSIC CULTURE FROM THE MID-1960S TO EARLY-1970S
}

\author{
Adil Johan
}

\section{Introduction}

On the 22nd of October 2013, I visited a modest exhibition on Malay youth music from the mid to late 196os in Singapore's Esplanade Library. The minimalistic and silent exhibition created by the Malay Heritage Centre of Singapore featured five two-sided colour panels displaying photographs and historical information about the Malay rock and roll bands of the popyeh yeh music era. It was part of a series of nostalgic Malay cultural exhibits sponsored by the Malay Heritage Centre ${ }^{1}$ intended to shed light on a vibrant but often occluded period of cultural history in the Malay Peninsula. Much like the quiet atmosphere of the 'musical' exhibition, the Malay youth of the pop yeh yeh era expressed a culture that was in need of silencing by the aggressive cultural policies implemented by the government authorities of Malaysia and Singapore. The following pages, in response to this renewed interest in pop yeh yeh, intend to give a voice to the contestatory discourses and issues that were articulated by Malay youth in the 1960s.

This chapter seeks to provide some much needed amplification of the study of Malaysian and Singaporean music in this era by observing the ways in which Malay youth of the mid-196os to early-1970s were implicated in cultural policies and conservative regimes. Moreover, such youth negotiated their differences with the older generation in divergent ways: some actively and proudly fashioned themselves with the subversive styles and sounds of the West while others voiced conservative concerns about such trends, effectively policing their peers with discourses of morality and tradition. While this chapter is not primarily concerned with

${ }^{1}$ Information about the Malay Heritage Centre's ongoing exhibits can be found on their website: http://www.malayheritage.org.sg/exhibitions.htm. 
government policy in relation to music, I discuss the ideas of two Malay film music icons: ${ }^{2}$ Zubir Said and P. Ramlee, whose ideas on Malay music culture inspired the implementation of the Malaysian National Culture Policy (NCP) that was drafted in 1971. Their reactionary comments on the erosion of Malay culture by youth-related lifestyles and musical dispositions provides an ideological frame of reference for the discourses of cultural nationalism that demonised pop yeh yeh youth.

I then proceed to discuss youth music culture in 196os Singapore and Malaysia followed by an observation of the 'yellow cultures' ${ }^{3}$ or subversive youth trends that caught the negative attention of Singaporean and Malaysian government authorities. The 'beat music' of English-language bands primarily based in Singapore in the 196os emulated music from British rock bands such as The Shadows and The Beatles. In time, English songs were adapted to Malay, and eventually, by the mid-196os, Malay youth started writing and performing original compositions in the styles of previously emulated Western rock bands. Attendant with such music was a vibrant array of youth fashions that included tight-fitting attire, sunglasses, mini-skirts for women and long-hair for men. The Singaporean and Malaysian state active in policing what was deemed degenerate 'yellow cultures' resulted in youth harassment and the banning of music performances. Youth themselves were also active in the 'policing' of their peers as fan letters in the Malay music magazine Bintang dan Lagu [Stars and Songs] indicate.

Finally, to provide an insight to the discourses on Malay youth and moral degeneracy in the mid-196os, I turn to the movie $A$ Go Go '67 (1967) directed by Omar Rojik for the Shaw Brothers' Malay Film Productions. This film was made during the waning years of Malay film production in Singapore and indicates an attempt by the film industry to attract a youth audience whose consumption patterns were straying from Malay cinema while being drawn towards local electric-guitar-band performances and their numerous vinyl record releases. My research suggests that the once popular means of disseminating Malay music through film ${ }^{4}$ was being

2 Zubir Said was one of the first Malay film music composers in the 1950 os and P. Ramlee was a prominent icon of the Malay film industry from the 1950s to 1960s, acting, directing, writing, singing, and composing for the numerous films in which he was involved.

3 Jones's (2001) book, Yellow Music, describes how the term 'yellow' was used in China during the Republican era to associate a degenerate and 'pornographic' quality to the popular music of Li Jinhui that blended 'American jazz, Hollywood film music, and Chinese folk music' (Jones 2001:6).

${ }^{4}$ In the 1950s, numerous singers for Malay films including P. Ramlee recorded film songs for record labels such as HMV, EMI, Columbia, Parlophone and Pathé (Sarji 2011: 
usurped by a renewed ${ }^{5}$ local record industry and its attendant pop yehyeh culture. The transition from film music to 'guitar-band music' contextualises the reactionary comments of film-music icons such as P. Ramlee, whose once non-traditional cosmopolitan musical and cinematic practices in the 195 os were being replaced by louder sounds and less conservative fashions. ${ }^{6}$

Malaysian government policy in the 1970 s operated within a framework of Malay ethno-nationalism that required clear delineations of what constituted 'pure' Malay culture. This led to the excessive removal or avoidance of elements that were regarded as 'foreign', 'un-Malay' and non-Islamic (S. Tan 1993:177-8; also see S. Tan 1992, 1989). State enforced 'ideologies' of purity 'can give rise to the opinion that safeguarding - that is, "guarding safe" a tradition - straight jackets it into a petrified form, forbidding it to be subjected to any processes of innovation and change that would feature in living, vital cultural' practices (Grant 2012:37). Youth cultures feature prominently as a threat to these 'national' traditions as youths are often at the forefront of change and innovation, regardless of whether they have overt political intentions to upset the status quo or revolt against authority.

In Malaysia and Singapore, there has been a marked disjuncture between development-oriented national agendas that are based on capitalist ideologies and the derogatively 'modern' young populace that are 'relentless' in the 'fashioning of... youthful selves through (the) consumption' of popular culture (Stivens 2012:170). These 'self-fashioning' youths spark 'moral panics' (Stivens citing Young 1971 and Cohen 1972) and 'social anxieties' in state authorities that respond by retaining and enforcing hegemonic state-sanctioned boundaries of modernity and morality (Stivens 2012:174). In line with this youth-state contestation, the role of the Malaysian government in controlling the 'threat' of youth cultures run parallel to their initiatives to regulate the performing arts:

290-8) For a detailed account of the 78 RPM record industry in Malaya prior to World War II, see S.Tan (1996).

5 The record industry was 'renewed' through the proliferation of 'beat music' bands in the 1960 . More research is required regarding the record industry centred in Singapore from the 1950 s to 1960 s but Pereira (2011) informs me that there were numerous independent record labels sprouting in Singapore in the mid-196os that capitalised on the proliferation of local youth bands.

6 Kahn (2006:126-31) discusses the notion of 'other' Malays that fall outside the conventional sphere of traditional 'Malayness', and uses P. Ramlee's films as complex casestudies that express a hybrid Malay culture that was Westernized yet rooted to a conception of indigeneity that recurred as a narrative of an idyllic Malay village (kampung) life in contention with an urban modernity. 
By introducing various policies, guidelines and institutions in the 1970s and 1980s, the government has tried to centralize and control the performing arts. Those art forms which are in line with the national culture policy and performances which adhere to the stipulated guidelines have been promoted and encouraged. However, those which are considered "anti-Islamic", those which are alleged to stimulate "violence" and those which are generally "undesirable" have been banned or censored... Even the popular music industry, dominated by transnational companies and shows promoters, has been subjected to the same intervening institutions and restrictions. (S. Tan 1992:303)

Tan's observations point to the pervasiveness of Malaysian state intervention in the arts and alludes to the role of state policies in constraining youth music cultures. Criteria for inclusion and exclusion are ambivalent; thus subjecting a range of cultural practices to prosecution, censorship, or repression. Hence, the youth who participated in musically-oriented counter-cultures - that were transmitted through a commoditised global market system of cultural consumption - would be at the centre of the government's initiatives to perpetuate a hegemonic notion of national culture. Furthermore, tensions existed (and continue to exist) between the state and the recording and entertainment industries interested in marketing 'subversive' but highly marketable trends to local youths.

This chapter seeks to reveal how young Malaysians and Singaporeans were actively shaping locally unique musical practices based on trends from the West that were at odds with state-defined notions of national culture. Conversely, it is apparent that youth agency was not fully present as the marketing initiatives of the entertainment and print industries mediated the representations of 'degenerate' youth in conflict with the 'repressive' state. My study seeks to unravel these issues historically and discursively, with a focus on Malay youths whose bodies and cultural practices were at the centre of contestation between state-sanctioned moral policing and the consumption of globally commoditised musical and cultural trends. Malay youth cultural practices of the 1960 initiated such contestations to national cultural ideology in Malaysia and Singapore; providing a 'template' for the discursive and physical repression of future youth cultures in Malaysia.

The Ideas of Zubir Said and P. Ramlee: Precursors to National Culturalism

Some of the earliest ideas for a national-culturalism emanated from the ideas of Malay music icons, Zubir Said and P. Ramlee. Aside from being 
prominent creators of post-war Malay music, towards the mid-196os, they became prominent critics of Westernisation in Malay music practices. Ironically, while both musicians sought to infuse a 'Malayness' to their musical creations, they adapted a diverse range of musical styles from the West and other Asian film-music practices such as Hindustani film songs. ${ }^{7}$ Despite their cosmopolitan musical backgrounds, the ideas that they proposed about developing and preserving a national culture would become standardised in the discourse about Malaysian national cultural policies post-1971. In this section of the chapter, I will examine some of their ideas that set the discursive tone for Malaysia's National Culture Policy of 1971.

Zubir Said was a musician and composer of Minangkabau descent who migrated from Sumatra to Singapore to become a prominent film music composer for Cathay-Keris Malay language films from the 1950 s to 1964 (Low 2012:24; R. Zubir 2012). Before becoming a citizen of Singapore in 1967 , he wrote a state anthem that would become the national anthem, Majulah Singapura. Since then, he has been revered as a Singaporean national icon. Recently, there has been renewed interest in him through a comprehensive biography of him (R. Zubir 2012) and a series of events to commemorate his cultural contributions to Singapore: a musical tribute concert at the Esplanade concert hall (12th October 2012) and a ten-day film screening highlighting his film music (National Museum of Singapore, 10-20th October 2012; see also National Museum of Singapore 2012).

Such celebrations of Zubir Said as a Singaporean national icon, in retrospect, are paradoxical to the Malay-nationalist initiatives that he proposed for the development of Malay music and arts. Of course, his ideas were proposed during a period when Singapore and Malaysia were on a shared national trajectory past British colonial rule. In 1957, the Federation of Malaya was declared independent from British rule. Singapore, along with the Borneo states of Sabah and Sarawak joined the federation to form 'Malaysia' in 1963. In 1965, Singapore separated from Malaysia to

7 For an account of the diverse Malay and Western musical styles used by P. Ramlee see Sarji (2011:275) A more contentious observation by Ef (2011:xix) argues that despite the internalisation of foreign musical styles by Ramlee his music ultimately expresses 'soulfully Malay' qualities. McGraw and Suriyanti Azmi (2009) however, argue that Ramlee's film music expressed a more heterogeneous but uniquely Malaysian musical aesthetic. Zubir Said, while working with the modern medium of film music and orchestration actively utilised and adapted 'traditional' Malay instruments and styles for his film scores. Peters (2012) analyses his film music stylistically as a 'synthesis of musical systems in neo-traditional music', while Rohana Zubir (2012) provides a detailed musical biography of her father emphasising his contribution to Singapore's national music repertoire which included the country's national anthem. 
form an autonomous 'island-state'. This complex history of national boundaries between Singapore and Malaysia are further complicated by the politics of ethnicity, whereby ethnic Malays form an increasingly marginalised minority in the former and are a ruling majority in the latter. Thus, prominent in the discourse of Zubir Said's writings was a notion of ethno-nationalism centred on Malay culture.

At a presentation given in 1956/57 on the use of the Malay language in music, Zubir Said observed a decline in the standards of Malay language compared to the 'glorious days of the Malay Sultanates (zaman gemilang Kerajaan2 Melayu)' stating that as a result of courtly patronage, musicians and artists were highly valued, while 'Malay singing and songs occupied a good position in the field of arts (nyanyian2 dan lagu2 Melayu mendapat kedudokan baik pula dalam bidang kesenian)' (Z. Said 1967:20). In the context of modern Malay society, he further stated:

The result of changes in the organisation of society leads to changes in the development of Malay sung arts. Singers (artistes) and poets do not receive adequate patronage and born in society are artists that do not take responsibility in the value of their creations. These changes have brought detriment to the songs and language used in songs due to the intrusion of foreign elements. ${ }^{8}$

To overcome this decline of local music culture, he proposed the following actions be taken by the state and the artistic community:

1. National elements need to be implanted as much as possible into Malay singing to preserve its uniqueness.

2. Foreign elements that are destructive must be eliminated and (foreign elements) that are beneficial should be accepted.

3. Songwriters and singers (artistes) must possess adequate knowledge about (the Malay) language (vocabulary) and language usage (grammar). ${ }^{9}$

Zubir Said's suggestions feature the primacy of language in preserving and effectively creating a shared national culture through the arts based

8 In the original: 'Akibat perubahan2 dalam susunan masharakat menimbulkan perubahan2 pula dalam perkembangan seni nyanyian Melayu. Biduan2 dan ahli2 pantun tidak lagi mendapat pemeliharaan yang baik dan dalam masharakat lahirlah-lah seniman2 yang tidak bertanggong jawab dalam nilai chiptaan-nya. Perubahan2 telah membawa kerosakkan pada lagu dan bahasa yang di-pakai dalam nyanyian akibat kemasokan unsor2 asing (Z. Said 1967:20)'.

9 Author's translation from the original. 
on Malay ethnicity. The inclusion of 'national' elements into 'Malay singing' provides an insight to the need to actively shape a national consciousness through music. While defining a specific Malay ethnicity is fraught with contestations and ambiguity (National Museum of Singapore 2011; Milner 2008; Barnard 2004), the emphasis of the Malay language as a unifier for a diverse range of peoples that inhabit the Malay Peninsula provides feasible grounds for a national identity. More importantly, this national identity would be forged through literature and music. Moreover, such identities would be solidified by the active preservation and systemisation of knowledge concerning the Malay language.

Another factor that contributed to this national cultural agenda is the selective exclusion of external cultures. This was an inclusive process in which cultural boundaries needed to be clearly marked. However, in the post-colonial nation-states of Malaysia and Singapore, this was problematic due to a multicultural population. In an ambiguous way, Zubir Said's suggestions mentioned the need to remove 'foreign elements' that were considered 'destructive' while retaining 'beneficial' ones. The ambiguity here lies in the subjectivity of what was considered 'foreign' and how 'good' and 'bad' influences on Malay cultural practices could be assessed. As further examples in the paper suggest, the nation-state would play a major role in assessing these criteria of inclusion and exclusion in the arts. Some of these criteria were also drawn from reactionary suggestions by cultural personalities such as P. Ramlee, who was coping poorly with the changing musical tastes of Malay youth.

P. Ramlee was the iconic director-actor-singer-composer of Malay films from the 1950 s to the 1960 s. However, towards the end of his career in the late 196os, he experienced a decline in popularity due to an impoverished local film industry and the rapid spread of popular music styles from abroad that rendered his musical inclinations outdated and un-marketable. In a speech given at the National Culture Congress in Kuala Lumpur (1971), he expressed his frustrations by denouncing youth music cultures and upholding the need for advancing traditional Malaysian music. ${ }^{10}$

Ramlee started his acting and song writing career in the early 1950s in Singapore, working for the Shaw Brother's Malay Film Productions. He was the first critically acclaimed Malay filmmaker, directing his first film, 'The trishaw puller' (Penarek becha) in 1955. Since then, he had won

10 P. Ramlee, 'Cara-cara meninggikan mutu dan memperkayakan muzik jenis asli dan tradisional Malaysia demi kepentingan negara'. Speech given at the Kongress Kebudayaan Kebangsaan, Kuala Lumpur, 16-20 August 1971. 
numerous awards for his music, acting and film productions. In 1964, he left Singapore for the soon to be separate nation state of Malaysia, continuing his film career at the newly set-up, under-funded, and inexperienced Merdeka Film Productions studio in Kuala Lumpur. He would make numerous films here until his death in 1973. Critics and historians lament that the 'quality' and reception of his Malaysian productions failed to supersede the standards of his Singapore films. Times and tastes were changing and P. Ramlee in this period - despite his vibrant and diverse cosmopolitan musical influences (McGraw and Suriyanti Azmi 2009) represented a bygone era of antiquated Malay culture that did not speak to the younger, 'groovier', 'long-haired', 'marijuana-smoking' and 'miniskirt-wearing' Malaysian youth of the seventies. ${ }^{11}$

P. Ramlee in his presentation observed the decline of traditional music in Malaysia and proposed solutions for this 'problem'. He lamented the encroachment of Hindustani music from India and music from the West that had

rapidly influenced the souls of our (Malaysian) youths to the point that these youths are unaware of their long hair (ala the Beatles), dress in 'Groovy' styles that are unfamiliar, smoke ganja (marijuana) and other things. There are also youths that wear short 'mini-skirts' due to the influence of pop musicians. ${ }^{12}$

At the end of his presentation, P. Ramlee stated eight points to address the decline of traditional music in Malaysia that stressed the importance of government intervention and responsibility in this matter:

1. The government must act vigilantly to expand asli (indigenous) $)^{13}$ and traditional music extensively

2. Radio and television must play an important role in broadcasting as much traditional and asli music as possible.

11 The documentary, 'Biography: P. Ramlee' mentions a concert of the 'Three Ramlees' in the late 196os, where P. Ramlee was 'boo-ed' by the young audience. Conversely, the Malay Heritage Centre exhibition features a picture of P. Ramlee performing alongside the popular pop yeh yeh band, The Swallows (source: EMI Music). Additionally, One of Ramlee's famous songs Bunyi gitar (Sound of the guitar) from the film, Tiga Abdul (The three Abduls, 1964, dir. P. Ramlee) is arguably a parody or accommodation of the emerging rock \& roll style of electric guitar bands.

12 The original (in Sarji 2011:36) reads: Secara lekas dapat mempengaruhi jiwa mudamudi kita Malaysia, sehingga pemuda-pemudi tidak sedar pula berambut panjang (ala Beattle [sic]), berpakaian 'Groovy' yang tidak ketentuan, menghisap ganja dan lain-lain. Pemuda-pemudi pula berpakaian 'mini-skirt' yang singkat, kerana terpengaruh dengan pemain-pemain muzik pop.

13 The asli genre meaning 'original', 'indigenous' or 'pure' is both a specific Malay rhythm and a repertoire of song types. Asli music instrumentation includes regional 
3. A (government-sponsored) program must be implemented that has two simultaneous outlets for the training of asli and traditional Malaysian music.

4. All schools (including vernacular schools) must teach asli and traditional music as a subject in the curriculum.

5. Nightclubs, hotels, restaurants and any public places must play and perform asli and traditional music.

6. Music that is at odds with Malaysian traditions must be reduced.

7. The government must encourage the producers of asli and traditional music by providing commensurate endorsement and sponsorship for their musical works.

8. The government must sponsor asli and traditional music festivals to (positively) influence Malaysians. (In Sarji:36-7, my translation.)

What is evident in these proposed 'solutions' is the constant emphasis and reliance of government assistance and intervention. Thus, Ramlee portrayed an uphill 'battle' against commercial popular music and saw government sponsorship as the only solution to maintaining a 'declining' indigenous culture. Furthermore, the youth that were increasingly overlooking his music for foreign popular music were at the centre of this problem. They were the generation uncontrollably succumbing to negative Western cultures effectively forgetting their local cultures and values. The only solution he saw to this was an active intervention of the state government.

Thus, through Ramlee's 'solutions' I observe discursively how Malaysian national consciousness was being entrusted solely to the machinery of the nation state. Where Malays once relied on their sovereign rulers to define and symbolize their culture, they now had to turn to the nationstate as an extension or replacement of that sovereignty in the modern world. At the end of the conference in which P. Ramlee presented his national cultural views about music, the National Cultural Policy of 1971 was drafted. This policy has remained as the Malaysian government policy concerning culture and arts to this day (Kementerian Penerangan Malaysia 2008)..$^{14}$

instruments such as the rebana frame drum and gendang two-headed drum as well indigenised Western instruments such as the violin and accordion. See Matusky and Tan (2004:330) for an example of the asli rhythmic pattern and Matusky and Tan (2004:321, 329-30) for examples of asli repertoire.

${ }_{14}$ The website of the Ministry of Information Malaysia (Kementerian Penerangan Malaysia) lists the updated policy but states that three main principles of the policy are based on the initiatives set out by the National Culture Congress of 1971. 
In the remaining pages, I will explore how youth music cultures in mid196os to early-1970s Malaysia and Singapore have featured as the centre of contention in the debate about national culturalism. These youth cultures posed a counter-cultural threat to the two newly emerging countries and hence, a wealth of reactionary as well as conciliatory discourses were expressed about youth freedom and degeneracy in conflict with conservative and locally rooted morality.

\section{Youth and Popular Music in 1960 S Singapore and Malaysia}

The 196os in Singapore and Malaysia was a vibrant and creative period for youth music culture. Youth music culture in 196os Malaya began as emulative practices that would eventually become localised. Rock and roll bands from Britain and America were imitated in the form of cover bands. This was followed by the translation of popular English-language songs into local languages like Malay and later, original songs were written and performed in Malay, English and local Chinese dialects. While other languages were present in Malayan youth music, I will limit my observations in this section to English-language and Malay-language bands based in Singapore and Malaysia with a focus on the musical translatability of youth music and the related youth cultural practices that were deemed degenerate by state authorities.

The 'beat music' of British bands such as The Beatles, Rolling Stones and The Shadows were major influences on the musical styles and band formats that were performed by Singaporean and Malaysian youth in this era. Aside from a pervasive culture of musically emulating Western popular styles among English-language bands, there was also a growing community of Chinese and Malay-language bands that combined these new 'beat' styles and guitar-band ensemble formats with lyrics sung in local dialects. The Malay-language adaptations of British rock would be termed pop yeh yeh in reference to The Beatles' She loves you, yeh yeh yeh (Lockard 1998:224; see also Pereira 2011:1; Matusky and Tan 2004:407).

Along with such loud and rhythmically-driven music, fashion statements such as mini-skirts for women and long-hair for men represented a vivid cosmopolitan counter-culture to the more conservative leaders and law-makers of both nations. The Singaporean and Malaysian nationstates were newly independent and desperately seeking to assert a distinct national cultural identity that was refined in modernity yet rooted to indigenous traditions. The 'beat music' youth cultures however, were 
seen as far from refined and far from local by the older generation of local artists and government officials. In fact, youth music culture of the $1960 \mathrm{~s}$ represented everything the post-colonial Singaporean and Malaysian nation-building project was against. In line with Jones's (2001:101-4) view of the 'doubleness of yellow music' of 1930s China, Malayan youth music signified a degenerate or 'pornographic' cultural expression that was also modern and translatable across national boundaries. The articulation of pop yeh yeh culture by young Malaysians and Singaporeans represented a threatening sexual freedom along with a borderless cultural practice that could not be bound by the rigid confines of a national culture and its attendant traditional morality. In the following pages, I will examine a few examples of Malayan youth music cultures that posed a countercultural threat to the national cultural state-making agenda of $1960 \mathrm{~s}$ Singapore and Malaysia.

\section{Disquieting Expressions}

In the 196os, the centre of production for guitar-band music for the entire Malay Peninsula was Singapore. International record labels such as Philips and Columbia-EMI had recording and distribution operations based in Singapore and were actively promoting and producing local talents. In the early 196os, a wealth of local bands were recorded performing English songs of American and British artists. A major appeal of this emulative industry was the accessibility of these local bands to local audiences at live shows. Siva Choy, a member of the duo called The Cyclones, relates the following:

...in the early '6os, television had not arrived. You heard (foreign) bands on the radio but couldn't see them. Occasionally, a movie might come into Singapore with bands and things. So what do you do? You look for anything that will substitute. So, suddenly a local band stands up and starts to play Rolling Stones. It was great. No videos, no cassettes. So we became substitutes. Everybody sounded like somebody else. The more you sounded like somebody else, the greater the hero that you became... As a result, people became extremely imitative (Interview in Pereira 1999:18).

One of the more successful English-language bands from the era, The Quests, also modelled themselves after The Shadows. They initially gained popularity by winning talent competitions in which they would play songs by The Shadows (Chua 2001:33-8). In fact, there were many 'sounda-like' band competitions in early 196os Singapore: local bands such as 


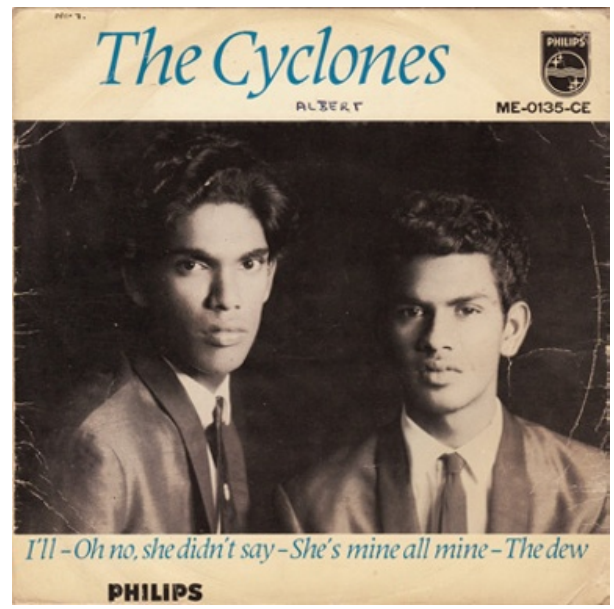

4. 1. The Cyclones (Courtesy of Joseph Clement Pereira).

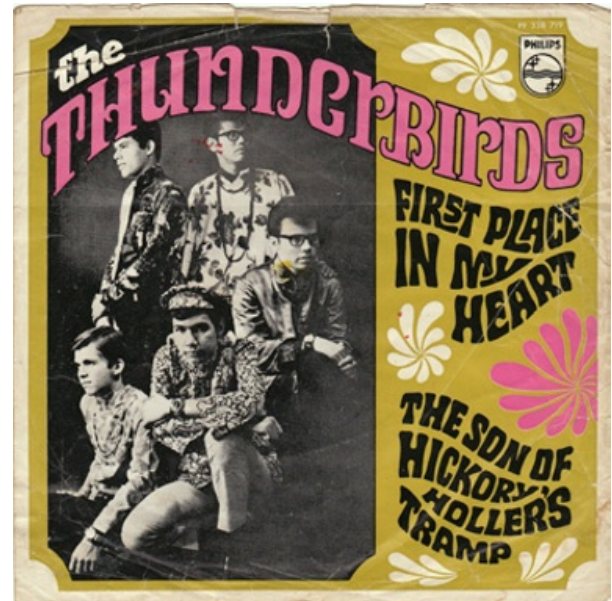

4. 2. The Thunderbirds (Courtesy of Joseph Clement Pereira).

The Stompers won the Cliff Richard and the Shadows contest, The Astronauts claimed the title of the 'Ventures of Singapore' and The Clifters were winners of the 'Rolling Stones of Singapore' competition (Pereira 2011: 2-3). There was also a 'Beatles versus Rolling Stones' competition that involved a finalist 'play off' between The Thunderbirds (who emulated the former) and Les Kafila (who mimicked the latter)- The Thunderbirds won the competition (Pereira 2011:3). 
Other notable groups such as Naomi and The Boys gained successful popularity in the Malay Peninsula with their cover version of the song 'Happy Happy Birthday Baby' by Margo Sylvia and Gilbert Lopez.

The adaptation of popular chart-topping English songs to the Malay language initiated a local recording music industry that was emulative of the West. This emulative industry which set the aesthetic tone for local music practices would eventually be articulated in more uniquely local expressions. In 1967, under the TK label, Ismail Haron who sang with the Vigilantes recorded Green green grass of home (Putman Jr.) as Senyuman terakhir (Last smile), La Bamba (Valens) as Mari menari (Let's dance), Hang on sloopy (Berns and Farrell) as Mari sayang (Come, Love) and You better move on (Alexander) as Pulang pada-ku (Return to me). ${ }^{15}$

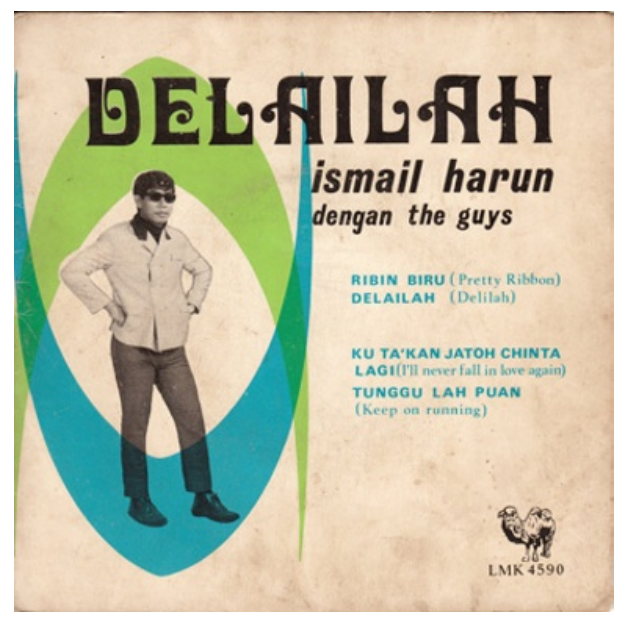

4.3. Ismail Haron's single, Delilah (Courtesy of Joseph Clement Pereira).

Ismail Haron based his recording career in the 196os on performing, adapting and writing Malay versions for popular English songs. His other notable recordings were Enam belas lilin based on 16 candles (Dixon and Kent), Delailah from Delilah (Mason and Reed) performed by Tom Jones and Jangan marah Lili (Don't be angry, Lili) adapted from Mohair Sam (Frazier) performed by Charlie Rich. ${ }^{16}$ Ismail Haron asserted that despite being labelled the 'Tom Jones of Singapore', he was more inclined to

15 Interview with Ismail Haron, 19 December 2005, conducted by Joseph Clement Pereira. Oral History Archives, National Archives Singapore; Malay Heritage Centre 2012; Pereira (2011:111).

16 Interview with Ismail Haron, 19 December 2005; Pereira (2011:112). 
African-American performers such as James Brown, Lou Rawls, Nat King Cole, Aretha Franklin and Ella Fitzgerald; however, he was constrained to covering Caucasian artists due to the demands of recording companies (Ismail Haron).

The mid-196os also saw the growth of Malay bands in Singapore and Malaysia called kugiran- an abbreviation for kumpulan gitar rancak (lively guitar bands) (Matusky and Tan 2004:407). Like the English-language cover bands these bands usually consisted of a core band fronted by a singer. Such singers were subject to change depending on the performance or recording project. Some popular singers and bands in the mid-196os from Singapore were Rafeah Buang, Maria Bachok, Sanisah Huri, Siti Zaiton, Ahmad Daud, Jefridin and The Siglap Five, A. Ramlie and The Rythmn Boys, Kassim Selamat and The Swallows, The Terwellos, The Hooks and Les Kafilas. These bands were characterised by their original compositions and vernacular or asli (indigenous) approach to Malay singing ${ }^{17}$ complemented by overtly Westernized musical style and instrumentation. ${ }^{18}$ A notable recording is the song $\mathrm{La}$ Aube recorded by Kassim Selamat and The Swallows sung in a Baweanese dialect. The song was even a popular hit in Germany; arguably making the group 'the most internationally recognised Malay Pop band of their time' (Malay Heritage Centre).

\section{Degenerate Practices}

In 1960s Singapore and Malaysia, prominent and complementary to the music-makers were the youth audiences. These youth adopted fashions that were considered outrageous or provocative, listened to their favourite Western or Western-derived music on the radio, actively collected music records, watched local TV programmes featuring local bands and singers and congregated in musical spaces and events such as band competitions and concerts. The most accessible of these live events were the 'tea dances' that were aimed at young adults, and the most prominent

17 By the 1930s, Malay musical culture was 'modernised' through the interactive 'fusion of Malay and Western elements', in which Malayness was presented in 'the singing style, the vocal ornamentation, the singer's emphasis on the last beat of the phrase, the linear texture, the cyclic drum rhythmic patterns, and the use of Malay syair texts' while the West was represented in 'harmony or implied harmony in or between the instrumental and vocal parts (a factor which strongly influenced melodic invention), close relationship between the text and the music, and Western melodic instrumentation' (S. Tan 1993:98).

18 Interview with Ismail Haron, 19 December 2005; Lockard 1998:226. 
fashion statements included short mini-skirts and form-fitting outfits for women, tight and slim trousers for men and towards the end of the 196os, long hair below the shoulders would be a pervasive trend among young males.

The tea dances of 196os Singapore were held on Saturday and Sunday afternoons for young patrons below the legal drinking age as no alcohol was served. Some venues in Singapore included the notable Golden Venus, a club located on Orchard Road, Celestial Room, The Palace, Springdale, The Prince's at Prince Hotel Garni and New World Cabaret (Pereira 2011:6; Chua 2001:85-8). It was an event where youth could have 'clean fun', enjoy live music, as well as congregate in their trendy clothes.

Joseph C. Pereira, author of two books on Singapore band-music in the 1960 s $(1999,2011)$ is an avid fan, record collector and producer of numerous compilation albums of Singaporean beat music from the 196os. During my research in Singapore for this chapter, I was fortunate to interview him at his home and view his vast collection of 45 RPM and 33 RPM records. Pereira maintains a modest but enthusiastic network of Singapore $1960 s$ music fans and record collectors across Singapore and Malaysia. Aside from his personal vinyl collection he showed me a collection of albums from the 1960s that had been converted to CDs by another fan. More so related to this study, his insights and personal memories of growing up in the era provided me with an intimate perspective of pop yeh yeh culture. He shares his personal experience of attending a tea dance in 1969 at the age of fifteen:

[The tea dance] was held in the afternoon from three to six and it was a basement club... I went with two friends. We paid the grand fee of one dollar which entitled us to a Coke... But the thing was that straight away, I told myself, "I'm out of my league"... [This was] because we were wearing short sleeve shirts and trousers- we looked like tourists! Then we look[ed] at the rest [of the people], and you know, because they were older teens or... [young] adults- these guys and gals- they looked damn cool, man! We looked like a bunch of tourists, wearing short sleeve shirts... Some were wearing fringe jackets, some were wearing corduroy, some were wearing Levi's corduroy [jeans], and tailored slacks... A wide range of fashions... [There were some who wore] sunglasses. All kinds of sunglasses... There were a lot of [young women wearing] mini-skirts. Of course, some of them wore pantsuits. ${ }^{19}$

19 Interview with J.C. Pereira, 21 October 2012, Singapore, on bands and youth culture in 1960 . 
It seems that appropriate fashion was a major factor among youths at these tea dances. Pereira expresses much amazement with the attire of the patrons and emphasised how embarrassed he was to be out of place in his attire ('we looked like tourists!'). Pereira also related to me the set-up of the club that included a 'bandstand', 'dancing stage' as well as 'tables and chairs where people sit and watch' the performances. Most of the dancing was done by male-female couples on dates, while a majority of the audience which was male would sit and observe the bands performing.

Unfortunately, this was the first and last tea dance that he would attend as tea dances were banned by the Singapore government on the 1st of January, 1970 - a few months after Pereira and his friends patronised the Golden Venus at Orchard Road. According to Pereira, tea dances towards the end of the 1960 s were notorious for ending up in fights, so the government viewed tea dances as a breeding ground for 'juvenile delinquency'. ${ }^{20}$ In fact, state antagonism towards youth culture in the late 196os to early 1970s was a major factor in the decline of such musical events as the Singaporean and Malaysian

... government campaign... in the 1950s to create a Malayan culture and reject 'yellow culture' or what were seen as degenerate external cultural influences began to have an impact. As local music was regarded as being heavily influenced by the West and associated with a culture of drug use and disorderliness, this led to the banning of, among other things, tea dances and other events featuring live music (J. Tan 2010, my emphasis).

Indeed, in the late sixties to early seventies, The Straits Times newspaper in Singapore abounds with articles on youth degeneracy in terms of 'yellow culture', 'flower people' ('Lim warns of flower people, yellow culture', The Straits Times, 13 January 1968) and the general paranoia about the 'hippie' movement and associated music cultures ('Need to play down "hippie trend" on TV', The Straits Times, 18 May 1970; 'Hippism does not start or end with pot and long hair', The Straits Times, 20 September 1970). This included the ban of the American film, Woodstock: Three Days of Peace, Music and Love ('Singapore censors ban pop colour film Woodstock', The Straits Times, 29 December 1970). This leads me to discuss another issue of youth 'degeneracy' and Singaporean and Malaysian youth in the late 196os to early 1970s: long-haired males.

The rise of long-haired male youth was considered such a problem that Singaporean government offices had a policy of serving 'males with long

20 Interview with J.C. Pereira, 21 October 2012. 


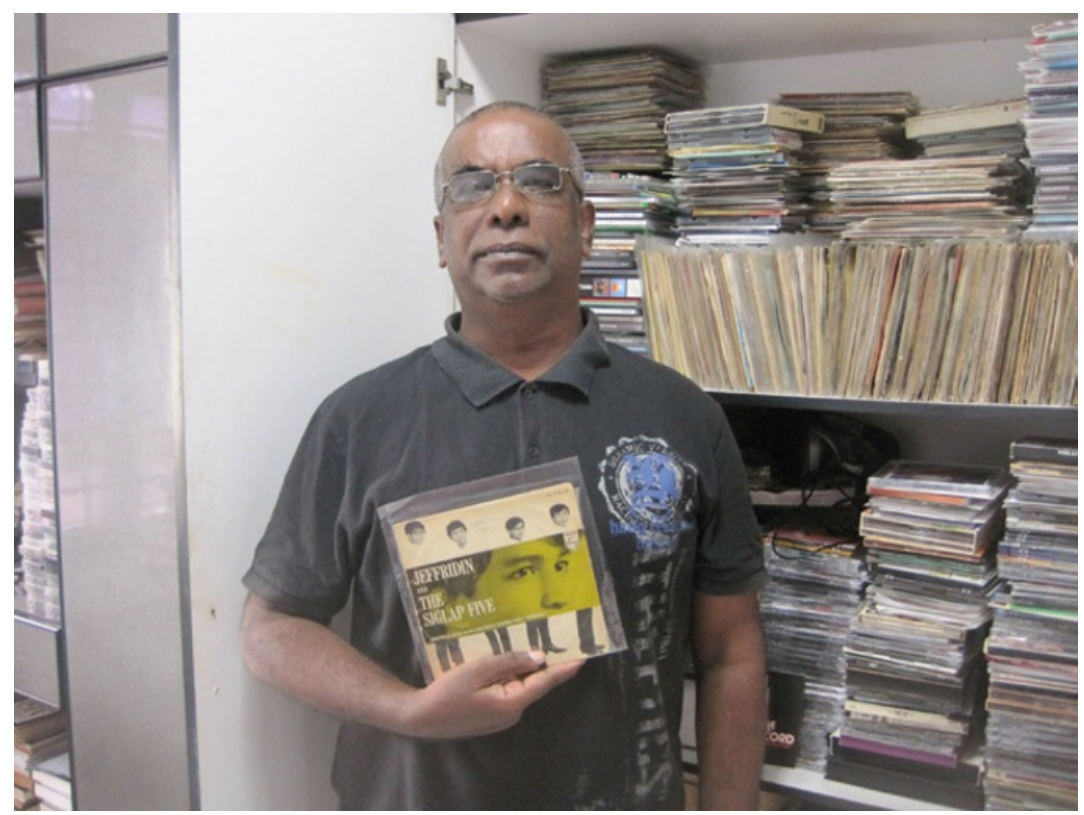

4.4. Joseph C. Pereira and his personal record collection (photo by author).

hair... last' (Chua 2001:56-7). ${ }^{21}$ In Malaysia, Johor state-backed scholarship holders were banned from having long hair alongside restrictions from participating in demonstrations and marrying without the consent of the scholarship committee ('Long hair ban on grant holders', The Straits Times, 17 November 1975). What constituted 'long hair' for males? According to an illustrated Singapore government poster titled 'Males with long hair will be attended to last', long-hair criteria for males included 'hair falling across the forehead and touching eyebrows', 'hair covering the ears' and 'hair reaching below an ordinary shirt collar' (cit. Singapore National Library Archives in Malay Heritage Centre). Pereira informs me from a personal experience he had with his friends - that police officers in 1970s Singapore would randomly harass and find fault with any young males who sported long-hair. These examples indicate that it was the bodies of youth that the state sought to assert its control. Unfamiliar and unconventional appearances were somehow linked to degeneracy and moral decadence ultimately at odds with the state vision of promoting a subservient national culture among youths.

${ }^{21}$ See also http://www.malayheritage.org.sg/MHCPortal/content/conn/ucmnhb/uuid/ dDocName\%3ANHBSVRAPP61620000040000 (page 12). 
Interestingly, 'policing' of the body also occurred among youths themselves. In the mid to late 196os Malaysian and Singaporean women were liberating their bodies through 'provocative' or revealing styles of dress. The issue of young Malay women in mini-skirts was a frequent topic of fan letters in the Singaporean-based, Malay-language music magazine, Bintang dan Lagu (Stars and Songs). A letter from someone who may be a young woman ${ }^{22}$ named Hanis denounces the wearing of mini-skirts as a provocatively revealing Western form of dress with the sole intention of attracting male attention. The writer asks why women should copy the fashions from abroad while ignoring local and more modest fashions (Bintang dan Lagu, July 1967, p. 51):

Mini-skirts are a type of clothing that exposes [a woman's] calves to the public. Is this what is called progress? Progress can be achieved without having to wear mini-skirts. And, by wearing baju kurong [traditional Malay female dress] we are able to attract males; we don't need to wear miniskirts for this... If we really want to wear short [revealing] clothes, wear underwear, isn't that even shorter [more revealing] ${ }^{23}$

The writer adds that local society is to blame for encouraging this indecent form of dress by holding 'mini-skirt pageants' (ratu mini skirt) and falling victim to the disagreeable influences of the West (Bintang dan Lagu 1967, p. 51).

This statement is unique in multiple ways. Firstly, the critique of miniskirts was voiced by someone who may be surmised to be a Malay woman. She advocated for a style of dress among her female peers that embodied traditional modesty as well as a progressive and modern outlook. Secondly, the writer raised some interesting issues about feminine sexual objectification: why should women expose their legs just to attract men and why should they be paraded in beauty pageants? Thirdly, the issue of Western cultural hegemony was raised, whereby Western fashion was threatening the survival of Malay clothes and cultural modesty:

${ }^{22}$ It is difficult to ascertain the gender of the letter writer as there is a possibility that the writer may be using an alias, a male writing as a woman, or even one of the magazine editors intending to generate interest in the magazine. For the purpose of this discursive study, I will deduce the writers' identities based on the content of their letter. What is important is to ascertain how magazine readers in the mid 196os would have interpreted or reacted to such letters.

23 The original (Bintang dan Lagu 1967, p.:51) reads: 'Mini-skirt ialah suatu pakaian yang mendedahkan betis kita kapada umum. Adakah ini dikatakan kemajuan? Kemajuan akan terchapai dengan tidak payah memakai mini-skirt. Dan dengan memakai baju kurong kita dapat menarek hati lelaki, tak payahlah dengan memakai mini-skirt... Kalau benar2 kita hendak memakai pakaian2 yang pendek, pakai sahaja chelana dalam, bukankah lebeh pendek?? 
Why must we copy the clothes that come from other countries, like Western countries (?) Aren't there enough clothes in our own country? While Western countries have never ever wanted to use our clothes, why then must we favour clothes that come from the West that are not suitable for us. ${ }^{24}$

The question is whether to view this letter as a conservative statement or a post-colonial feminist one. Ironically, it seems to present both possibilities for interpretation, but I interpret this writer as an autonomous female voice that is paradoxically bound by the cultural restraints of patriarchal Malay culture. Conversely, 'modesty' in Malay culture isn't necessarily patriarchal, as it is the female voice in this case that is actively advocating such cultural values. As such, with regards to the culture of wearing mini-skirts, this writer employs a discourse similar to conservative critiques of youth culture such as the ones stated by P. Ramlee and subsequently implemented government policies that attempted to promote traditional, non-radical-Western values.

In later issues of the same magazine, conservative views towards the mini-skirt trend are expressed. A letter expresses antagonism with miniskirts in a very curt manner:

For me miniskirts are like jackfruit covers. The top is wrapped tightly, while the calves and thighs are shown to the general public. I feel that instead of wearing miniskirts it is better not to wear anything at all; that is even more attractive for men' (Bintang dan Lagu, September 1967). ${ }^{25}$

Another, more neutral letter observes how new male and female fashions are far from different in their tightness and attendant youths' attitude:

While young women are stylish with their miniskirts that reveal parts of their thighs, young males show off their shirts and trousers that are tight or 'fancy', as these young adults like to say. No matter what clothes they wear, no one can tell them otherwise because they will reply with an answer that is unsettling (rude or inappropriate) (Bintang dan Lagu, November 1967$, p. 48$){ }^{26}$

24 Mengapakah kita mesti meniru2 akan pakaian yang datangnya dari negeri lain, saperti negeri2 dari Barat. Tidakkah chukup pakaian yang ada pada negeri kita? Sedangkan negeri2 Barat tidak pernah bahkan tidak mahu manggunakan pakaian2 kita, mengapa pula kita mesti mempertinggikan lagi pakaian yang datang dari Barat yang tidak sesuai dengan kita. (Bintang dan Lagu 1967, p. 51).

${ }_{25}$ Buat saya miniskirt itu saolah2 saperti sarong nangka. Diatas tutup rapi, sedangkan betis dan peha ditunjok2kan dikhalayak ramai. Rasa saya dari memakai miniskirt itu lebeh baik jangan memakai langsong, itu lebeh menawan hati lelaki.

${ }^{26}$ Kalau sipemudi bergaya dengan miniskirtnya yang menonjolkan sabahagian pehanya, maka kapada sipemuda, mereka beraksi pula dengan baju dan seluar yang ketat2 
Both of the letters quoted above are indicative of a general uneasiness towards these new fashions. It is difficult to ascertain the gender of the letter writers quoted, but it is certain that their stance is quite conservative in relation to the content of the music magazine to which they write. In my general overview of Bintang dan Lagu issues from 1966-1967, I saw numerous pictures of female artists in mini-skirts and other form-fitting attire in line with the youth fashions of the mid to late 196os. Therefore, these letters perhaps only revealed a minority opinion about youth dressing styles and its attendant morality. Furthermore, it is possible that these letters were contrived by magazine editors to entice readers. Regardless, it is interesting to note that there was a debate over the issue in a musicoriented publication targeted at youths. Beyond the music, bands and singers that were prominently featured in the magazine, the discourse of mini-skirts and fashion directly involved the fans or participants of Malaysia and Singapore's 196os music culture.

The debate over mini-skirts in Bintang dan Lagu ended ${ }^{27}$ on a more liberal note with an article titled 'Miniskirt, Apa salahnya gadis2 Melayu memakai miniskirt? (Miniskirts, What is the harm in Malay women wearing miniskirts?)' (Bintang dan Lagu, November 1967, pp. 4-5). The article summarised previous fan letters against and in support of mini-skirts and made an attempt to investigate the issue. The writer $(\mathrm{s})^{28}$ of the article 'investigated' by visiting the predominantly Malay Geylang Serai district in Singapore to see the extent of mini-skirt-wearing among young Malay females. They ascertained that 'the situation' wasn't as bad as previous fan letters had depicted as the amount of women wearing unreasonably short skirts were 'very small' (Bintang dan Lagu, November 1967, p. 5). The article concludes by noting that young Malay women are 'still capable of looking after themselves and adapting to the times'29 (Bintang dan Lagu, November 1967, p. 5). Despite conservative reactions towards youth fashions that were seen as detrimental to local culture, values and morals,

atau 'fensi', kata muda-mudi dewasa ini. Biar apa jua pakaian yang mereka gayakan, tidak saorang pun boleh menegor-sapa mereka kerana pasti mendapat jawapan yang tidak bagitu menyenangkan.

27 The last available copies of the Bintang dan Lagu magazine at the British Library St. Pancras, London are the issues from 1967; thus, 'ending' the mini-skirt debate until more research is done to retrieve later copies. There is also a possibility that this magazine ceased publication after 1967. As archived copies of this particular magazine are rare, more research is required regarding the production history of this publication.

28 No writers are credited in this article.

29 '... maseh lagi pandai menjaga diri dan menyesuaikan diri mereka dengan pengedaran zaman' (Bintang dan Lagu, November 1967, p. 5). 
there remained a discourse that sought to reconcile such youth culture as reasonable or even progressive and adaptive to modern times. I argue that a cosmopolitan agency was present in the debates and discourses among the youth of 1960s Malaysia and Singapore. This agency was articulated in different ways with divergent opinions about morality and the role of youth in the emerging nations of Malaysia and Singapore. Conservative or reactionary voices proclaimed a moralistic positionality by using modern tropes of national culturalism to safeguard traditional values. Arguments in favour of youth cultures sought to reposition the moral compass towards ideas of progress, modernity and adaptability to changing times. Thus, agency exists in both views and such opinions were articulated in cosmopolitan mediums that provided a new space for these oppositional ideas to interact. While the recording industry created music for countercultural youths to consume, print media ${ }^{30}$ provided a discursive space for youths to expose and express the disjuncture between such countercultures with traditional values, national identity and modernity.

The Malay film industry, waning in popularity towards the end of the $1960 s$, provided a further space for the articulation of this counter-cultural discourse of youth culture. In the following section, I discuss how one Malay film tried to consolidate older values with the trendy youth music and culture of late 196os Malaysia and Singapore. The film in its attempt to draw a young audience provided a narrative that tried to challenge conservative stereotypes of Malay youth degeneracy by portraying such youths as morally-capable individuals.

\section{A Go Go '67}

It is suggested that the popularity of popyehyeh bands coincided with the decline of the musically-oriented Malay film industry (Lockard 1998:226). It is difficult to ascertain whether pop yeh yeh directly impacted the 'decline' of Malay cinema but there is an interesting example of the two 'worlds' or cultures interacting in the Shaw Brothers Malay-language film, A Go Go '67 (1967), directed by Omar Rojik. The film contains a loose plot about a young woman and man who are members of a kugiran and more

30 For a thorough discussion on the cosmopolitanism and Malay nationalist activism in print media see Barnard and Van der Putten (2008). Barnard and Van der Putten believe that it was the cosmopolitan intellectual environment of Singapore in the 1950s that led to significant creative and political advances in the Malay arts and literature. A cosmopolitan conception of Malayness was being formed and the imperative for the creation of a modern 'Malaysian' state was being articulated with utmost agency, 'in the Malay language' (Barnard and Van der Putten 2008:148). 
importantly, features pop yeh yeh performances of twelve groups and four dance groups. While the musical performances are the main highlights of the film, the narrative that ties the numerous musical performances together contains discourses about kugiran youth culture clashing with conservative Malay values. As a case study of the clash between youth culture and state ideology in 196os Malaysia and Singapore, I will discuss such contestatory discourses about youth culture present in the film A Go Go '67. Interestingly, the film provides a moral compromise that favours the youth, while portraying stereotypical conservative views that abhor youth culture.

The film's storyline evolves around a young woman named Fauziah (portrayed by Nor Azizah) who, against her conservative and well-heeled father's wishes, sings in a pop yeh yeh band. Her boyfriend, Johari (played by Aziz Jaafar), is the leader of the band who sings and plays the keyboard. Fauziah's father (Ahmad Nisfu), is extremely antagonistic towards Malay youth culture to the point that he abruptly intervenes one of Fauziah's band rehearsals by kicking a drum kit and proceeds to scold her and her bandmates: 'If you want to be Satan, go and be Satan. Don't bring my daughter to be Satan with you! What is all this yeh yeh yeh?'31

Despite his disapproval, Fauziah makes long 'speeches' about how youth aren't as bad as her father believes. She admonishes her father about his misconceptions about youth:

Not all youth are immoral and delinquent, father. Also, not all people who are religious are good, father. I am an adult. I know right from wrong. You know father, a lot of them (youths) do not have permanent jobs. So, by directing their interest towards music, they are able to fill the emptiness of their lives and avoid criminal activities... Father, do you like hearing of our youths stealing, thieving, extorting because of the emptiness in their lives? ${ }^{32}$

Her father doesn't agree as he views such youths as lost beyond 'repair'. He then laments how the West with their civilised ways and innovations have failed to control their 'wild youth movements (angkatan liar)'.

31 'Ingat! Kalau kau nak jadi syaitan, pergi jadi syaitan. Jangan bawa anak aku jadi syaitan bersama! Apa ni, 'yeh yeh yeh' ini apa?'

32 Bukan semua pemudi begini tak bermoral dan jahat, ayah. Juga tak semua orang yang alim baik, ayah. Saya dah besar. Saya tahu buruk-baiknya. Ayah tahu, kebanyakkan dari mereka itu tak mempunyai pekerjaan yang tetap, ayah. Jadi, dengan menumpuhkan minat mereka terhadap muzik, mereka dapat mengisi kekosongan hidup dan terelak dari perkara-perkara jenayah... Ayah suka mendegar pemuda-pemuda kita mencuri, merompak, menyamun kerana kekosongan hidup mereka? 
In order to control her from her social and musical activities, Fauziah's father arranges her to be married to her cousin.

Later in the film, Fauziah's father makes a comment about the misfortunes of the world, and mentions a need to do charity work. His wife chides him by saying that his plans for charity never materialise. He then schemingly says that if he collects considerable donations he will receive a medal for his contributions to society and the government. He then denounces the youth for their aimless ways, noting that they are never concerned about the welfare of the poor.

Upon overhearing these remarks, Fauziah decides to organise a charity concert for orphans. She gives Johari five hundred dollars to organise the event and recruit bands to participate. Johari asks why she is suddenly planning this event. Fauziah then makes another speech-like proclamation:

My father always accuses that youth like us are the thrash of society that are absolutely useless. I want you (Johari) to prove to society, especially my father, that we can be used for a good cause as long as people know how to make use of us. ${ }^{33}$

In the next scene, Fauziah's house is prepared for the marriage but Fauziah is nowhere to be found as she is attending the charity concert. More performances from kugiran bands ensue. She returns from the concert and says to her father that she has accomplished her duties and is ready to be married according to her father's wishes. Unfortunately, her engagement was called off as her potential in-laws were fed-up of waiting for her return. Fauziah didn't even intentionally avoid the wedding as she just wasn't informed when the wedding was going to be held! Her father is too ashamed about the whole escapade and angrily tells Fauziah to leave his sight.

Shortly after, a group of reporters come into the now gloomy house looking for Fauziah. They glowingly inform her parents that Fauziah and Johari just organised a very successful charity event and are to be commended for their contributions to society. As the reporters congratulate her on her success, she mentions that the true organiser of the event was her father. In the end Fauziah's parents are seen apologising to Johari and all is well.

33 'Ayah selalu menuduh bahawa pemuda-pemuda dan pemudi-pemudi seperti kita ini adalah sampah masyarakat yang sudah tak berguna langsung. Yah (Fauziah) mahu Joe (Johari) buktikan pada masyarakat terutama pada ayah Yah sendiri bahawa kita dapat digunakan untuk sesuatu tujuan yang baik asalkan seseorang itu tahu menggunakannya.' 
A Go Go '67 provides an informative perspective on the discourses about youth in contention with national culturalism in late 1960 s Singapore and Malaysia. The film was shot in Singapore during the last years of the Shaw Brothers Malay Film Productions division; marking the end of an era of Malay film production in Singapore. Fittingly, the film is an attempt by the fledgling industry to appeal to the very youth culture that was a major factor in the Malay film industry's 'demise'. As such, the narrative tries to portray a conciliatory stance by portraying the youthprotagonists as decent human beings, contrary to much of the statements made by cultural icons such as P. Ramlee and Zubir Said. The film paints a stereotypical archetype of reactionary conservatism in Fauziah's father, replete with statements about the immorality of youth, their uselessness to society and their devious, delinquent and devilish tendencies. Interestingly, the film's altruistic protagonist, Fauziah, becomes a staunch advocate for youth culture, proving to her father that youth are morally grounded people with the capacity to care of others and use their art for good causes. Fauziah's character is thus a noble and self-sacrificing archetype that is a participant of youth culture as well as an upholder of 'traditional' moral values. In fact, she ends up displaying greater moral initiative than her conservative and opportunistic father.

Ironically, the film's altruistic narrative also asserts moral expectations on youth and in effect, patronises their moral inclinations. Despite this attempt at discursive reconciliation, youth music remained predominantly commercial and government initiatives continued to repress youth culture as indicated in the consequent banning of youth-music activities and venues (Pereira 2011). The film, while being a commercial production that targeted a youth demographic provides an important document of the discourses and disjunctures that circulated around the vibrant musical culture of Malay youth in the late 196os. Past the one-dimensional characters, moralistic condescension and far-fromsubversive narrative, $A$ Go Go ' 67 presents viewers with an idea of the music and lifestyles of the Malay youth of the pop yeh yeh era albeit through the mediating gaze of a declining local commercial film industry desperately seeking a youth audience.

\section{Conclusion}

Youth music cultures in Malaysia and Singapore have always been at the locus of contention for nation-making policy and its conservative advocates. While studies on Malay youth and music have provided pertinent 
examples of this contention with the government (Stivens 2012; Yusof 2010; S. Tan 2006; Ibrahim 1995; S. Tan 1989, 1993, 1992), it was the music cultures of the 196os in the Malay Peninsula that ignited the history of contestation between the emerging Singaporean and Malaysian state with youth cultural practices. The 196os was a transitional period of independence, post-coloniality and independence for Malaysia and Singapore. As such, state-makers from both countries were desperate to create a local-traditional cultural imaginary for their emerging nation-states. Pop yeh yeh was immediately antithetical to the state vision, and was a hindrance to the nation-making project. The music of popyehyeh was unmistakably Western in influence and Malaysian and Singaporean youth were aligning themselves to more radical and subversive cultures of the West. These youth in their cultural practices incited 'moral panic' (Young 1971; Cohen 1972 cited in Stivens) among the conservative ruling elite, which resulted in the formation and implementation of policies and interventions to limit their activities and spaces of expression. Much like the Malaysian 'black metal crackdowns' in the early 2000s, 'the construction of Malay cultural identities as embodied in the body politics of urbanized Malay youths' led to state actions to control and repress what was deemed as deviant cultural practices' (Yusof 2010:180). Of course, in the case of commercially-based music cultures there are ever present ironies with regards to ethnocratic-state hegemony and capitalist logics of global cultural consumption. Stivens in her recent study of Malaysian youth culture points out the following:

There are... contradictory links between, on the one hand, the social disciplining imposed by the state and religious moral projects, to produce the hoped-for new, responsible, self-fashioning young citizen-subjects required by the new order discourses - male and female - and on the other, the relentless fashioning of selves by young people through their massive engagement in the new consumption ordained by the enthusiastic embrace of capitalist development. (Stivens 2012:190)

While not as 'transgressive' or subversive as the more recent heavy metal youths (Tan 2002 cited in Stivens:182), pop yeh yeh culture can at least be seen as counter-cultural in its convivial embrace of 'the new' through processes of 'self-fashioning' that while initially emulative of external trends, became uniquely local in its expression of Malaysian and Singaporean youth aspirations. These youth had music that was enjoyed in Europe (Kassim Selamat and the Swallows), they adapted foreign songs to Malay and infused new meanings into them (Ismail Haron), they sparked new but shortly-lived interest to a declining film industry, and more 
importantly, they danced the Go-Go in stylish abandon and let their hair down freely; much to the misunderstood disgruntlement of the Malaysian and Singaporean state authorities.

All these cultural practices intersected in complex ways: cosmopolitan expressions of agency were articulated, yet the looming presence of larger market forces such as the print, recording and the film industries were instrumental in the dissemination of such cultural practices and lifestyles. The state enforced national cultural policies on Malay youth that imposed a racial-traditional conception of morality with attendant behavioural expectations. It was thus the disquieting loudness of 'degenerate' Malayan youth practices in the mid-196os to early-1970s that unsettled the Singaporean and Malaysian nation-making project of cultivating a culturally refined and obedient citizenry. Ironically, the looming presence of the global post-colonial music and culture industries of the West still exists to challenge the presumed self-fashioning agency of musical cultures around the world (Stokes 2004). Such post-colonial transnational market and ideological forces complicate the tensions between youth practices and state policies in Malaysia and Singapore in the present albeit with different cultural manifestations. Beyond the scope of this chapter, further reflections are required on the complex relationship between the state, youth, gender, post-coloniality and global capitalism in the Malaysian-Singaporean cultural sphere.

\section{References}

Barnard, T.P. (ed.) Contesting Malayness: Malay identity across boundaries. Singapore: Singapore University Press, 2004.

Barnard, T.P. and J. van der Putten. 'Malay cosmopolitan activism in post-war Singapore', in: Michael D. Barr and C.A. Trocki (eds), Paths not taken. Political pluralism in post-war Singapore, pp. 132-53. Singapore: NUS Press, 2008.

Chua, H. Call it Shanty: The story of The Quests. Singapore: Big Books, 2001.

Grant, C. 'Rethinking safeguarding: Objections and responses to protecting and promoting endangered musical heritage', Ethnomusicology Forum, 21-1:31-51, 2012.

Ef, Yusnor. Muzik Melayu sejak 194o-an. Kuala Lumpur: YKNA Network Sdn. Bhd, 2011.

Yusof, A.M. 'Facing the music: Musical subcultures and "morality" in Malaysia', in: S.G. Yeoh (ed.), Media, culture and society in Malaysia, pp. 179-96. London: Routledge, 2010.

Ibrahim, Z. Popular culture at the crossroads: Malay contemporary music (an analysis of creativity and the industry). Cendekia, Kuala Lumpur: Akademi Pengajian Melayu, University Malaya, 1995 .

Jones, A.F. Yellow music: Media culture and colonial modernity in the Chinese jazz age. Durham/London: Duke University Press, 2001.

Kahn, J.S. Other Malays: Nationalism and cosmopolitanism in the modern Malay world. Singapore: Singapore University Press, 2006. 
Kementerian Penerangan Malaysia. 'Dasar kebudayaan kebangsaan', Kementerian Penerangan Malaysia, http://pmr.penerangan.gov.my/index.php/component/content/ article/88-dasar-dasar-negara/238-dasar-kebudayaan-kebangsaan.html (last accessed 24 October 2012), 2008.

Lockard, C.A. Dance of life: Popular music and politics in Southeast Asia. Honolulu: University of Hawai'i Press, 1998.

Low, Z.B. 'Biography of Zubir Said', in: National Museum of Singapore (ed.), MAJULAH! The film music of Zubir Said, pp. 22-5. Singapore: National Museum of Singapore, 2012.

Matusky, P. and S.B. Tan. The music of Malaysia: The classical, folk and syncretic traditions, Aldershot: Ashgate, 2004.

McGraw, A.C. and Azti Nezia Suriyanti Azmi. 'Music and meaning in the independenceera Malaysian films of P. Ramlee', Asian Cinema 20-1:35-59, 2009.

Milner, A.C. The Malays. Chichester, West Sussex: Wiley-Blackwell, 2008.

National Museum of Singapore (ed.) Melayu: Politics, poetics and paradoxes of Malayness. Singapore: NUS Press, 2011.

National Museum of Singapore. MAJULAH! The Film Music of Zubir Said. Singapore: National Museum of Singapore, 2012.

Pereira, J.C. Legends of the Golden Venus: Bands that rocked Singapore from the '6os to the '9os. Singapore: Times Editions, 1999.

_. Apache over Singapore: The story of Singapore sixties music. Vol. 1. Singapore: Select Publishing, 2011.

Peters, J. 'Zubir Said and his music for film', in: National Museum of Singapore (ed.), MAJULAH! The film music of Zubir Said, pp. 74-9o. Singapore: National Museum of Singapore, 2012.

Sarji, Ahmad. P. Ramlee: Ertiyang sakti. Petaling Jaya, Malaysia: MPH Distributors, 2011.

Stivens, M. 'The youth, modernity and morality in Malaysia', in: W. Mee and J.S. Kahn (eds), Questioning modernity in Indonesia and Malaysia, pp. 169-200. Singapore: NUS Press; Kyoto: Kyoto University Press. [Kyoto CSEAS Series on Asian Studies.] 2012.

Stokes, M. 'Music and the global order', Annual Review of Anthropology 33:47-72, 2004.

Tan, J. 'Popular music in the 196os', Infopedia Singapore, http://infopedia.nl.sg/articles/ SIP_1658_2010-04-15.html (last accessed 26 October 2012), 2010.

Tan, S.B. 'The performing arts in Malaysia: State and society', Asian Music 21-1:137-71, 1989.

- 'Counterpoints in the performing arts in Malaysia', in: J.S. Kahn and F.K.-W. Loh (eds), Fragmented vision: Culture and politics in contemporary Malaysia, pp. 282-307. Honolulu, HI: University of Hawai'i Press, 1992.

- Bangsawan: A social and stylistic history of popular Malay opera. Singapore: Oxford University Press, 1993.

. 'The $78 \mathrm{rpm}$ record industry in Malaya prior to World War II', Asian Music 28-1:1-41, 1996.

- . 'Dissonant voices: Contesting control through alternative media in Malaysia', http://geekrawk.wordpress.com/2006/o1/21/dissonant-voices-contesting-control -through-alternative-media-in-malaysia/ (last accessed 18 October 2012), 2006.

Zubir, Rohana. Zubir Said, the composer of Majulah Singapura. Singapore: ISEAS Publishing, 2012.

Zubir, Said. 'Menuju tahun 1967', Filem Malaysia 1:20-1, 45, 1967.

\section{Filmography}

Omar Rojik. A Go-Go '67. Singapore: Shaw Renters (S) PTE LTD, 1967.

\section{Interviews}

Interview with Ismail Haron. Interview conducted by Joseph Clement Pereira. Oral History Archives, National Archives Singapore, 19 December 2005.

Interview with J.C. Pereira. Bands and youth culture in 196os. Singapore, 21 October 2012. 